\title{
3. Journalism training aid by Australians A case study in Solomon Islands
}

\begin{abstract}
After the ethnic clashes and generally poor plight of Solomon Islands at the turn of the millennium, the country has been the recipient of substantial international foreign aid, which has included journalism education and training, particularly from Australia. However, little independent research has been done about the role of Australian trainers and the history of journalism training in this period of change and restoration. This article seeks to provide a point-in-time report on journalism training in an aid context, in a bid to provide a baseline for future investigation of changes in the media landscape and training in Solomon Islands. This research draws on in-depth interviews with engaged stakeholders in Solomon Islands, including journalists, civil leaders and government figures. It also discusses the Australian government-funded media aid programmes, including the Solomon Islands Media Assistance Scheme (SOLMAS) and its unnamed predecessor.
\end{abstract}

Keywords: journalism, development, foreign aid, journalism education, journalism training, Australia, Solomon Islands, SOLMAS

\section{ALEXANDRA WAKE \\ RMIT University, Melbourne}

\section{Introduction}

OLOMON ISLANDS is the poorest country in the Pacific (Pacific Islands, 2014) and typically has relied on foreign aid for more than 50 percent of its gross domestic product (Feeny \& McGillivray, 2010, p. 83). It has some 635,027 citizens spread over about 1000 islands and atolls, with around 80 percent living in rural areas (Index Mundi, 2016). While there are 63 language groups, the majority of the population is Melanesian (95.3 percent), Polynesian (3.1 percent), Micronesian (1.2 percent) (CIA, 2016).

To make sense of the country's media it is necessary to acknowledge the country's past, its recent history and economic underpinning. A former British protectorate, Solomon Islands gained independence in 1978. Ethnic violence (between the Gwale people's Isatabu Freedom Movement (IFM), and the Malaitans, 1999-2003), government malfeasance and endemic lawlessness undermined the young nation's stability. The Islands' problems were complex, and made worse 
by inequitable distribution of wealth from nickel mining, illegal tree felling without compensation to landowners and bad weather conditions for the production of traditional subsistence crops (Social impact assessment of peace restoration initiatives in Solomon Islands 2004; DFAT, 2004; Hou, Johnson \& Price, 2013).

Around 75 percent of the workforce are engaged in subsistence farming and fishing. Economic growth depends largely on logging and timber exports, however, access for large-scale commercial development is complicated by the fact that 80 percent of land (and inshore fisheries) is communally owned (Kabutaulaka, 2005b).

In the late 1990s, ethnic tensions over land brought the country to the brink of economic disaster, and in March 2003 Australia answered a third call for help from Solomon Islands Prime Minister, Sir Allan Kemakeza (Kabutaulaka, 2005a) and in July 2003, led a multinational intervention force to restore peace and disarm the ethnic militias. This intervention force, the Regional Assistance Mission to Solomon Islands (RAMSI), remained for a decade, until 2013.

Calling itself 'a partnership' between the people and government of Solomon Islands RAMSI drew members from 15 Pacific Island countries, including Australia. Its mandate covered law and order, rebuilding institutions and establishing conditions under which the nation could achieve social and economic recovery.

The RAMSI team stated that one of its most significant jobs was to help develop the country's media to give the people of Solomon Islands access to information, and therefore better governance (Social impact assessment of peace restoration initiatives in Solomon Islands, 2004, p. 36). In 2005, senior Solomon Islands journalist Johnson Honimae (Solomon Islands rapped for weak role, 2005) was reported as saying 'Solomon Islands experienced social unrest because the media had not played its role as a watchdog on the leadership of the country since independence'. He also suggested the media was failing to report the views of all people:

the media only picked on national leaders but did not touch tribal leaders or Solomon Islands middlemen who abused the trust of landowners for the sake of filling up their pockets and their foreign bosses'. (Solomon Islands rapped for weak role, 2005)

While the Australian government did not overtly state that it had a specific political or ideological ambition for its aid programme, it used bureaucratic language which acknowledged it needed the media for state-building initiatives such as multiparty elections and parliamentary reporting, strengthening governance practices, targeting corruption and providing a stable framework for economic growth (AusAID 2006, pp. 43, 61). The Australian government specifically acknowledged the role of the media in ensuring that the facilitation of nation building was conducted with transparency (Australian Government, 2007). 
Assistance to the media was part of RAMSI's initial programme of recovery in 2003, and specifically assistance with the training and education of journalists was one of its immediate priorities. However, RAMSI's first priorities were questioned. Singh and Prakash (2006) suggested the initial work by RAMSI was not appropriately planned:

In the midst of these tumultuous changes, powerful nations in the region, such as Australia, need to get proper assessments of the situation on the ground rather than rush in with short-term, ill-conceived and narrowly focused interventionist policies. (Singh \& Prakash, 2006, p. 82)

\section{Research method}

A mixture of documentation and interviews has informed this article. It draws on official reports of aid agencies, the media and the responses to open-ended questions when interviewing a cross-section of stakeholders of the time. These enabled me to construct a description of the process of building media skills in post-conflict Solomon Islands and start to consider its implications as a step towards a stronger Fourth Estate. The material relied on here is part of the work paying specific attention to the Australian aid workers involved in programmes in young nations, through the experience of Solomon Islands research, undertaken for a doctorate in the period 2011-2015 (Wake, 2015).

The 21 stakeholders interviewed in Solomon Islands included junior and senior journalists, media owners, trainees, journalism trainers, government officials and civil society leaders. They represented a range of ages and experiences, including one working in a public relations capacity for RAMSI; a former general manager of Solomon Islands Broadcasting Corporation (SIBC); the then-owner of The Solomon Star; a former journalist-turned-politician; a former journalistturned-government-media-adviser; the local head of Transparency International; and a Catholic priest who ran media training programmes, particularly for community radio. The others were all journalists of varying levels of experience.

Procuring Australian governmental documentation about the media training component of the RAMSI project was difficult. I battled to obtain access documents from Australian Broadcasting Corporation International under Freedom of Information regulations for several years. Australian Broadcasting Corporation International attempted unsuccessfully to argue that: 'any misinterpretation and/ or misuse of the content in those documents carries the real risk of potentially damaging Australia's relationship with Solomon Islands and other Pacific entities' (ABC International, personal communication, 5 April, 2011).

The Freedom of Information provision that was used to delay the application for access to materials was 'interference with sovereign relations'. The use of this clause indicated that the ABC International managers - those who sent the trainers 
to Solomon Islands, and those who hosted them - saw the role of educating journalists as a political rather than an educational strategy.

The broad themes for analysis were about journalism in Solomon Islands, holding power to account, the Fourth Estate, cultural practices, respect for journalists, good reporting, and journalists' values.

\section{Early media strengthening}

In 2005, through a contract managed by Australian Broadcasting Corporation $(\mathrm{ABC})$ International, three senior Australian journalists took up training/ mentor roles, two at SIBC (on the SIBC/ABC Project Solomons), and one at the major newspaper, Solomon Star. They quickly discovered that education is an inherently political occupation (Kincheloe, 2008) and found themselves in strife with political leaders in an environment unlike their own professional background in journalism in a liberal democratic nation state (Solomons broadcast chief condemns action against Australian reporter, 2005). There are few publicly available documents about their work, but it is known that at least one, who was employed as news adviser/trainer with the SIBC News and Current Affairs Division, arrived in January 2005 and was told by the Solomon Islands government to leave in December 2006.

Two of the ABC International staff involved were approached for this research but declined to be interviewed. One was a senior ABC journalist with experience in public and commercial broadcasting in Australia and New Zealand. This trainer had 30 years' experience in the industry (including in Pacific broadcasting) and held a diploma of management. The second trainer also had more than 30 years' media experience, in both commercial and public service radio, including experience in regional Australia for the $\mathrm{ABC}$. The third trainer was a long-time newspaper journalist with considerable editorial experience. Another staff member was approached to be interviewed, but declined, quoting contractual obligations not to speak about the project. There was nothing to suggest in any of the public biographies that at the time of their appointments the ABC International staff had any knowledge of Solomon Islands, its culture or languages, but one had reported on the Solomon Islands conflict.

Several Solomon Islands journalists and officials interviewed for this project confirmed that the presence of $A B C$ trainers within the SIBC newsroom did not sit well with the government of the day, with uneasiness about the types of stories local journalists were being encouraged to write. As Kincheloe (2008) notes, knowledge is power, and the 'how and what' people are taught always serves a political agenda. A veteran Solomon Islands journalist who worked in government communications at the time remembers one $\mathrm{ABC}$ trainer had found herself on the outer with the then Prime Minister: 
He [Sogavare] seemed to believe the Australian media is very influential in the Pacific, even Asia, some parts of Asia. That's why he had this feeling that it's not fair to have Australian journalists or media workers positioned in some key media organisations here. He's got the fear that they might influence local reporters to report unfairly on the government, especially on his side. Which is also, I think, in some ways true. (Anonymous Government Official, Solomon Islands, INTERVIEW)

Another senior Solomon Islands journalist believed the Australian journalist's departure had more to do with management inadequacies at the SIBC, as both the owner and staff were happy with the work of the journalist at Solomon Star:

It really didn't have anything to do with whether [the journalist] was an Australian or not. I think it was just the SIBC itself. .... So many people are sitting in it too comfortable and not doing anything, and when you get somebody coming in to try and bring some changes that would make the place move, you get antagonism. Everybody's out to protect their jobs, and I think that's basically what happened to [the journalists]. (Anonymous Senior Journalist, Solomon Islands, INTERVIEW)

Another cause for resentment by Solomon Islands journalists was due to the Australian government failing to set clear boundaries in regard to the Australians' aid work:

I think a lot of it was based on no clear communication from AusAID about how this project would run, and what were the roles of the advisers. I think they also came in at a pretty bad period for the media at that time. We were waiting for a lot of help, and what we got at that time wasn't what we expected. (Anonymous Senior Journalist, Solomon Islands, INTERVIEW)

The first media intervention in Solomon Islands, then, had mixed results. While the owner of the Solomon Star was happy with the assistance provided in his newsroom by an experienced Australian newspaper journalist, there were tensions over the presence of $\mathrm{ABC}$ journalists in the Solomon Islands national broadcaster, with some feeling that the Australian trainers were unfairly targeted for criticism that was better directed at the ineffectual management of SIBC.

\section{Media after the tensions}

The Solomon Islands media market grew quickly in the years immediately after the cessation of the ethnic tensions, with new newspapers, National Express and Island Sun, direct competitors to the market-leader Solomon Star. As all newspapers were published in English they required readers to be literate in that language. They were also for people living in Honiara, with none for the outer islands. 
Radio remained the most important medium for most Solomon Islanders. The national public service radio broadcaster SIBC was described as having the grandfather position in the market and there was a perception that other media depended on it for their news and information (Tebbutt Research, 2010, p. 27). However, by 2011 the SIBC was facing commercial competitors from Paoa Radio, ZFM100 and Gud Nius Redio (a semi-commercial Christian FM station).

Television, introduced post-2003, had little reach, with distribution limited and affordability another barrier. In 2010, the internet was still a dream (Tebbutt Research, 2010, p. 17).

With 80 percent of the population illiterate and unable to afford TV, radio was important, along with traditional methods of distributing news and information, still a part of Solomon Islands life, particularly in remote areas. The village chief and elders, especially those with relatives in Honiara, were often entrusted with delivering news. Church announcements were also important:

The conch shell, fire and drum beating are still used in more remote areas. Modern media and communications have almost completely replaced these methods. When they are used, they are often simulated by media. (Tebbutt Rsearch 2010, p. 19)

Some isolated and poor places still heard news via short-wave or two-way radio broadcasts from Gizo or Munda in the Western province.

Tebbutt's audience research found that Solomon Islands' media were perceived as being Honiara-centric, even by those who lived in the capital. The report identified three particular sensitivities: political, provincial and cultural, classified by Tebbutt Research as apprehension about independence, accuracy and balance.

\section{Second stage media strengthening}

The media-strengthening initiative, the Solomon Islands Media Assistance Scheme (SOLMAS), was launched in 2008. It was an AusAID-funded medium for development projects delivered through a partnership between RAMSI and the ABC. Promoting its aim as 'improving the reach and quality of Solomon Islands media', SOLMAS set out to provide media training and consultancy to help the country develop the resources and skills necessary for journalists to publish accurate, well researched and in-depth coverage of their own country-a vital aspect of a well-functioning parliamentary democracy. SOLMAS was funded by RAMSI and managed by the $A B C$ through the self-funding consultancy ABC International Development.

The SOLMAS project staff included an ABC manager based in Honiara, appointed in September 2008, two 'craft' trainers based in Honiara, and a project 
manager based in Melbourne. One of the trainers was a senior journalist from the $\mathrm{ABC}$, the other a former $\mathrm{ABC}$ rural reporter turned senior documentary maker. Other trainers were brought in from Australia on occasion. At the time of the field research the Honiara-based manager had been in Solomon Islands just over two years. She came with extensive experience in indigenous broadcasting and commercial television, with an MBA from a regional Australian university.

The SOLMAS project was practically a textbook example of the phenomenon referred to in Public Sentinel: News Governance Reform (Norris, 2010) outlining the need for a strengthening of news media institutions, alongside work with the public sector. In the foreword to Norris' book, Sina Odugbemi wrote:

officials in donor agencies point out the sensitivity of many governments when it comes to any attempt to make the news media independent of government and better able to hold the government to account. (Norris, 2010, p. ix)

The SOLMAS programme claimed it was using 'best practice' for post-conflict fragile states; as the manager noted, 'We are doing a lot of talking with the stakeholders. We are doing more listening than talking'. This attention to listening instead of talking was noted by many of the Solomon Islands journalists:

This is where I think SOLMAS has been more successful, because they've actually consulted with us, and asked us what we want to out of assistance that they can provide. (Anonymous Senior Journalist, Solomon Islands, INTERVIEW)

Several civil society leaders in Solomon Islands, not linked to the SOLMAS training, suggested the ABC trainers would never truly understand Solomon Islanders, their attitudes and behaviour. A businessman, born in Solomon Islands and at the time heading the local chapter of Transparency International, noted that in Solomon Islands, meaning was often conveyed in a way that could only be understood by Solomon Islanders: it could simply be in the choice of a particular word.

There was general insistence that it was best, where possible, to use trainers from Solomon Islands, then Melanesia, then the Pacific, before an Australian or New Zealander, because locals and people from the region better understood the environment and culture.

It was also noted that international trainers were 'fine' to teach the basics of journalism, but they could not understand the stories. Local journalists were required to explain the background and culture to stories:

... sometimes you listen to the reports from overseas journalists who come through (the country) and we just laugh. They have no idea what's 
happening and it's not even close to what the real issues are. (Hawkins, television journalist, Solomon Islands, INTERVIEW)

On the other hand, a constant pressure in the training provided by SOLMAS was to train journalists to overcome their fear of interviewing men who held 'powerful positions and influence', and to ask 'higher' questions (Dinh \& Heriot, 2010, p. 50):

SOLMAS training to date has considerably improved the ability of journalists to overcome fears of intimidation and confront the 'big men' of Solomon Islands over matters such as corruption. This training must continue through exercises that challenge beliefs and through the involvement of authority figures in training so that journalists can ask meaningful and sometimes confronting questions without fear. (Ferguson \& List, 2010, pp. 8-9)

\section{Programme goals of SOLMAS}

The SOLMAS project had five stated key components: strengthening Solomon Islands government and industry-based regulatory policy framework; strengthening the capacity of the commercial and community-based media and improving internal and external recognition of their roles; strengthening SIBC effectiveness and appropriately differentiating its roles as a public broadcaster and emergency service provider; maintaining a flexible support fund; and managing programmes (Ferguson, personal communication 2011). Of these, the first three were considered most significant for this research.

Those working on the SOLMAS project knew there were serious risks to its potential success, and these were given detailed consideration in the inception plan (Ferguson, 2009). Risks identified by SOLMAS were: a decline in political stability or the security situation; political interference undermining media independence; the economic situation declining and natural disasters preventing implementation.

In what appears to be an attempt to avoid some of the earlier problems between the Solomon Islands government and the Australian training journalists, the SOLMAS staff worked with the Media Association of Solomon Islands (MASI), to keep an appearance of distance between them and the broadcast and print media. Affiliated with other organisations, including the Pacific Islands News Association (PINA), MASI had received some support from UNESCO. In mid-2011 MASI officially had 14 members, although one new newspaper was not yet a member and dues had not been paid by a number of member organisations. Through MASI, the Australian staff had been hosting training sessions for the country's journalists every two weeks for two years.

Many of the country's journalists acknowledged the value of SOLMAS 
consulting with the group on what the media required in terms of training and support. Senior journalists, however, wondered at the sustainability of the weekly training model, and favoured the support of more senior Solomon Islands staff within the newsrooms:

I think especially we need to understand that SOLMAS will not be here for long. The capacity building of especially MASI will be vital. (Priestly Habru, Senior Journalist, Solomon Islands, INTERVIEW)

From the outset, the SOLMAS project documentation detailed apprehension that MASI might be unwilling or not completely transparent in providing access to its existing plans; that its members might be unwilling to allow access to staff for skills analysis or to contribute to shared training, or to allow their staff to participate in training opportunities. Further potential risks identified with work at SIBC included a legislative framework which impeded the SIBC's financial sustainability and the corporation's level of willingness to be transparent in providing access to existing plans and in revising plans and strategies.

Although there was criticism of parts of the SOLMAS project, those interviewed in Solomon Islands agreed that although the project was only at its midway point in 2011 at the time of the field work, the Australian staff were working steadily towards the goal of building capacity among the media. Journalism classes had begun at Solomon Islands College of Higher Education, weekly training sessions for election coverage on a Saturday morning had turned into bi-weekly sessions on a Tuesday, and senior reporters and editors were agitating for more international experience to develop their skills. One long-time Pacific journalist, turned RAMSI public relations officer, was enthusiastic in her praise for the SOLMAS work:

We're in the process of developing a sense of a culture of journalism that is much healthier... this young generation... are getting a lot more stories, they're going after stuff. They're gaining in confidence, and they're playing a much more significant role in shaping the debate in this country. (O'Callaghan, RAMSI PR and former Journalist, INTERVIEW)

However, only a little earlier an all-media audience survey and qualitative report concluded that the media were still struggling with "poor infrastructure, access, affordability, rapidly changing cultural values, Westernisation, and a leapfrogging of technologies'(Tebbutt Research, 2010, p. 5).

In 2015 skills acquisition for journalists was still being pursued, even by the Prime Minister, Manasseh Sogavare, who, in announcing the Prime Minister's Media Excellence Award for a top journalist said the prize was a scholarship in journalism studies. The Prime Minister said that, ' $\ldots$ being a good journalist 
would help the Solomon Islands to move forward in development and also help the country to trust the work of the media' (Solomon Islands: 'Breed good journalism' plea by PM, 2015).

Much of the initial training organised by SOLMAS was focused on three areas: craft skills, technical skills and knowledge/awareness raising. The craft skills courses were on writing and grammar for print/radio/television; presentation for TV/radio; editorial and newsroom management; and analysis of political information. The knowledge and awareness-raising courses included reporting on corruption and following the law; code of ethics and freedom of press and responsibilities; court and police reporting and understanding policing issues (Dinh \& Heriot, 2010, p. 17).

Working with MASI, SOLMAS organised a series of workshops where journalists and political leaders prepared for the 2010 election. For the media, in-house training assistance was offered, along with short courses that any journalist, regardless of employer, could attend. More than 44 training days were held, focusing on skills such as grammar (from basic to advanced); news writing for radio, print and television; and story structure. Effort was channelled into education about election processes and issues of governance, as for many of the younger journalists this was their first election. Training covered electoral awareness; voter awareness and education (with Solomon Islands Electoral Commission); analysing election manifestos and the role of women in maintaining political balance (Ferguson, 2011). Although training was centred in Honiara, some was done in the provinces by Solomon Islanders who had been through train-the-trainer courses.

Using the 2006 election coverage in the Solomon Star and SIBC as a basis, SOLMAS worked with MASI on how to provide better coverage. As well as the training outlined above, they also organised pre-election forums for the candidates. There was also some in-house training: despite the Sogavare government being fiercely against placing media trainers within newsrooms, the owners and journalists all preferred in-house training. Employers preferred it because staff did not need time off to travel to training. Journalists liked the immediate feedback on the work they were doing.

Only a few international trainers were brought in, including an election specialist from the ABC. Ferguson reported that the work of the Australian journalism trainer was welcomed: 'The National Express wrote an article on him. He was hero worshipped' . (Ferguson, SOLMAS Manage, (INTERVIEW)

At the time of her research interview Mary O'Callaghan, the RAMSI public affairs officer, an award-winning journalist married to a Solomon Islander, had overseen six elections in Solomon Islands. She argued that coverage of the 2010 election was the most impressive, in terms of delivering real-time information, 
the first-ever images of voting in provinces and a comprehensive network of SIBC to enable live crosses from all over the country on polling day, vote counting, and reactions to the different results. But in contrast, the late John Lamani of the Solomon Star gave little credit to SOLMAS and MASI for the improved election coverage, claiming his staff already had the skills to effectively cover elections and that the SOLMAS staff had favoured his competitors over him.

\section{Effectiveness of SOLMAS}

Interviews in Solomon Islands revealed wide appreciation from local officials, community organisations and journalists for the work of SOLMAS. Senior journalists were already hailing the project as having built capacity among journalists for the future.

All stakeholders agreed that support of the media sector in Solomon Islands would be needed for quite some time and all, but Lamani of the Solomon Star, agreed the SOLMAS training structure was a useful model for other countries. However, many warned that there should not be any direct export of the SOLMAS model to other places, even in the Pacific, because there was no one-size-fits-all formula:

There's an elegant simplicity to this structure, that is probably pretty transferable, because it is not complicated. The ownership thing with the local media, and the project's taking guidance from that, and working then very closely and collegially on an ongoing basis. That's one thing that's impressed me with SOLMAS. ... It's an ongoing, organic process if you like. (O'Callaghan, RAMSI PR and former Journalist, INTERVIEW)

ABC International, which managed SOLMAS, undertook three 'Independent Progress Reviews' over the life of the project, (O'Keeffe, 2012). The O'Keeffe review used OECD DAC criteria to assess the projects' relevance, effectiveness, efficiency, impact, sustainability, gender equality, monitoring and evaluation and analysis and learning. O'Keeffe concluded her report by recommending that media support continue in Solomon Islands, but that a new programme be designed to succeed SOLMAS with an emphasis on communication for development ('C4D'). She noted an effective media in Solomon Islands would remain essential as an enabler of informative, accurate and balanced communication (O'Keeffe, p.11).

O'Keeffe saw that SOLMAS had remained highly relevant to RAMSI objectives and had embarked on 'an ambitious but successful programme' of engagement with the broad range of the country's media (2012, p. 4). She dismissed disquiet by RAMSI about a high turnover among journalists after their training, noting that journalists left for other positions within the community, and as such the SOLMAS training continued to benefit local media. 
O'Keeffe noted the SOLMAS project had lessened the many critical gaps caused by government inadequacies and the dire financial situation under which most media organisations operated. Nonetheless she warned that there was a danger that SOLMAS was creating a degree of dependence and displacing, or even replacing, the growth of local solutions (O'Keeffe, 2012, p. 10).

\section{Conclusion}

This article has provided a benchmark for further detailed examination of the issue of foreign aid and media education in Solomon Islands. It acknowledges that aid funding comes with a political agenda and that there are difficulties in evaluating the effectiveness of media education where recipient countries did not start as empty vessels to be filled with Australian values and behaviour. Drawing on the thinking of Kincheloe (2008), this article acknowledges that students (of journalism, or of anything else), need to be aware that power comes through attempts to win people's consent, by social and psychological means.

Despite some early political mistakes in the way media assistance was conducted by Australian staff, the later SOLMAS project performed some important work, especially around the 2010 election, with staff acutely aware of the limitations of the project and of the work of expatriate trainers.

This article also raises concern about ABC International's lack of transparency over the SOLMAS project (in fighting access to documentation about the project). It is ironic that the $\mathrm{ABC}$ International managers in Australia clearly saw their role firstly as part of Australian foreign policy, rather than journalism trainers/supporters of the Fourth Estate in the Pacific.

One of the biggest impediments to improving the quality of the Solomon Islands media was not in the SOLMAS terms of reference, but in the educational level of those working as journalists. The low level of education and status of journalists in Solomon Islands made it difficult for local staff to fulfil their role as the Fourth Estate. Many simply did not have the background in economics and history, nor the cultural and social capital, to ask probing and important questions of Solomon Islands politicians and other powerful figures - the questions needed if journalism is to provide the vital role of government watchdog.

A generational change in Solomon Islands newsrooms was hailed by some as refreshing, but others suggested it had resulted in a lowering of standards. The exodus of senior staff moving into government and NGO roles had left many newsrooms short of seniors to provide mentoring and guidance for the younger journalists. The wages and working conditions were blamed for a large part of the turnover.

The Solomon Islands College of Higher Education (SICHE) had started an accredited basic journalism certificate, led by a Solomon Islander with assistance from part-time Solomon Islands journalists. Prior to the establishment of this 
course, students seeking a career in the media needed to train in other countries. The 15-unit certificate course was considered to be of a slightly higher level than a similar one offered in Vanuatu, in that it was just two subjects short of a diploma. It started with 25 students, but only 14 students continued. At the time of this research field work in 2011, the lecturer in charge was criticised for not having the depth of knowledge needed as many of those enrolled had practical experience and particular views about what they still needed to learn. Staff and assistant tutors all complained about the lack of equipment. A lack of resourcing meant that the handouts were not specific to Solomon Islands, but were Australian or from other Pacific nations.

So, while the SOLMAS brief was wide-ranging and gave staff the opportunity to influence the media environment through both technical advice and financial assistance, it was not wide enough to influence all sectors that needed to improve in watchdog journalism. By linking the Australian aid work practically to election reporting, SOLMAS could demonstrate tangible outcomes but it was less clear that these would continue to be improvements over time.

However, for a true understanding of the evolution of media skills and journalism in the Solomon Islands, a longitudinal — and independent study is required as the nation matures.

\section{References}

AusAID (2006). Australian aid: Promoting growth and stability. White Paper on the Australian Government's Overseas Aid Program, Australian Government, Canberra.

Australian Government (2007). Building demand for better governance: New directions for the Australian Aid Program, Position Statement and Program Guidance. Canberra, ACT.

Department Foreign Affairs and Trade (2004). Solomon Islands: Rebuilding an island economy, DFAT.

Dinh, K \& Heriot, G. (2010). Independent assessment progress report. Melbourne: Australian Broadcasting Corporation International Development.

Ferguson, C. (2009). Solomon Islands Media Assistance Scheme SOLMAS: Inception report and annual plan. Melbourne: Australian Broadcasting Corporation.

Ferguson, C. (2011, March). List of skills themes [to A. Wake].

Ferguson, C. \& List, J. (2010). Phase 2, quarterly report 3. Melbourne: Australian Broadcasting Corporation International Development.

Hou, D., Johnson, E. \& Price, S. (2013). Defending the forest in the clouds: Public interest law in Solomon Islands. Asia Pacific Journal of Environmental Law, 15, 167-75.

Kabutaulaka, T. T. (2005a). Australian foreign policy and the RAMSI intervention in Solomon Islands. Contemporary Pacific, 17(2), 283-308, 518.

Kabutaulaka, T. T. (2005b). Global capital and local ownership in Solomon Islands' forestry industry. In Globalisation and governance in the Pacific Islands. Canberra: Australian National University. 
Kincheloe, J. L. (2008). Knowledge and critical pedagogy: An introduction. Exploration of educational Purpose 1. Milton Keynes, UK: Springer.

Norris, P. (Ed.) (2010). Public sentinel: News media \& governance reform. Washington, DC: World Bank.

O'Keeffe, A. (2012). Independent progress review of the Solomon Islands Media Assistance Scheme (SOLMAS) Phase 3. Melbourne: Australian Broadcasting Corporation International Development.

Pacific Islands (2014). The World Bank. Retrieved on July 24, 2014, from www.worldbank.org/en/country/pacificislands/overview.

Singh, S \& Prakash, S. (2006). Politics, democracy and the media: Case studies in Fiji, Tonga and the Solomon Islands, Pacific Journalism Review, 12(2), 67-85.

Social impact assessment of peace restoration initiatives in Solomon Islands (2004). Suva: Pacific Islands Forum Secretariat.

Solomon Islands rapped for weak role (2005). Solomon Islands Broadcasting Corporation. Retrieved on October 25, 2014, from www.scoop.co.nz/stories/WO0505/S00163.htm.

Solomons broadcast chief condemns action against Australian reporter (2005, April 14), BBC Monitoring Asia Pacific, p. 1.

Tebbutt Research (2010). Audience market research in Solomon Islands. Southport, Qld. Wake, A. (2015). Aiding journalism: Australian journalism educators and their work in post-conflict states. Unpublished doctoral thesis. Melbourne: Deakin University.

The author would like to acknowledge the editing assistance of Rilke Muir. Dr Alexandra Wake brings 30 years of journalism and 15 years of teaching experience in formal education settings in Australia, Ireland, South Africa, the United Arab Emirates and in the Pacific. She has been elected six times to the national executive of the Journalism Education and Research Association, is on the education advisory board for the Hunter Mental Health Institute's Mindframe programme, and was an academic fellow for the Dart Center for Journalism and Trauma. She has presented research papers at the past three World Journalism Education Congresses in Belgium, South Africa and New Zealand. Her research work is focused on the teaching of practical journalism skills. alex.wake@rmit.edu.au 